\title{
Supercritical Fluid Extraction and Stabilization of Phenolic Compounds From Natural Sources - Review (Supercritical Extraction and Stabiliza- tion of Phenolic Compounds)
}

\author{
Mário Roberto Maróstica Junior*, Alice Vieira Leite and Nathalia Romanelli Vicente Dragano
}

Faculty of Food Engineering, Campinas State University (UNICAMP), P.O. Box 6121, 13083-862 Campinas-SP, Brazil

\begin{abstract}
Phenolic compounds are components commonly found in fruits and vegetables. Recently, they have been subject of considerable scientific and therapeutic interest mainly due to their antioxidant properties and related healthpromoting benefits, as confirmed by the numerous papers devoted to various properties of these compounds. Thus, the extractions of phenolic compounds with functional properties from natural sources have attracted special interests. Supercritical fluid extraction offers a number of advantages over conventional extraction methods above all in relation to the conditions employed during the extraction process that ensures minimal alteration of the active phenolics and the healing properties could be more easily preserved. This work provides an updated overview on the principal applications of Supercritical fluid extraction in recovery of bioactive phenolics emphasizing the effects of temperature, pressure, addition of co-solvents and time on the extraction yield of these compounds and their antioxidant activities for a possible applications in food, cosmetic or pharmaceutical industries.
\end{abstract}

Keywords: Phenolic compounds, supercritical fluid extraction, stabilization, recovery.

\section{INTRODUCTION}

Recently, investigations regarding the extraction of phenolic compounds from natural products have attracted special interests. This is due to the phenolic's health-promoting attributes, which play a vital role in the prevention of cardiovascular illnesses, certain kinds of cancer, diabetes, brain dysfunction or other conditions associated with the aging process [1]. The biological mechanisms of these possible effects have been attributed to their antioxidant properties through several possible mechanisms, such as their ability to scavenge free radicals, break radical chain reactions, directly reducing peroxides and stimulating the antioxidative defense enzyme activities [2].

One of the most important areas of research in food technology is the isolation of natural compounds with functional properties from natural sources [3]. Since these active compounds in herbal plants usually are present in low concentrations and they are usually very complex, researchers are focused on the development of more effective and selective extraction methods for their recovery from the raw materials. On this way, the extraction and purification processes are essential when they are used in the preparation of dietary supplements, nutraceuticals, functional food ingredients, food additives, pharmaceutical and cosmetic products [4].

In general, an analytical procedure for the determination of phenolic compounds involves the basic steps of isolation from a sample matrix, separation, identification and quantification. Extraction is the main step for the recovery of these bioactive phytochemicals and the ultimate goal is the prepa-

*Address correspondence to this author at the Faculty of Food Engineering, Campinas State University (UNICAMP), P.O. Box 6121, 13083-862 Campinas-SP, Brazil; Tel: ++55 19 3521-4059; Fax: ++55 19 3521-4060; E-mail: mario@fea.unicamp.br ration of a sample extract uniformly enriched in all components of interest and free from interfering matrix components [5]. It is influenced by their chemical nature, solvent and method of extraction employed and presence of interfering substances [6]. The extraction has been accomplished by traditional extraction processes, such as solid-liquid extraction, using solvents with different polarities, such as methanol, ethanol, acetone, ethyl acetate and water, pure or mixed [6-8]. These methodologies imply in the co-extraction of non-phenolic substances such as sugars, organic acids proteins and pigments, which can interfere on antioxidant evaluation. One alternative is the use of solid-phase extraction (SPE), which can be used to separate these compounds and to obtain more purified extracts [7,9].

However, there are drawbacks associated with classical extraction techniques such as the need for large amounts of solvents, time consuming and considerable waste products treatment [10]. Supercritical fluid extraction (SFE) could be an environmentally beneficial alternative to the conventional organic solvent extraction of these compounds. In addition, the SFE processes are fast, selective and the products are free of residual solvents.

The most of phenolic compounds are sensitive, unstable and very susceptible to degradation. The major degradation factors are the temperature, the presence of oxygen and light. Supercritical fluid extraction (SFE) provides relatively clean extracts, free from certain degradation of labile or easily oxidized compounds which may emanate from lengthy exposure to high temperatures and oxygen, which can occur during the traditional extraction techniques $[8,11]$. Hence it is important to understand the factors which influence the stability of polyphenolics compounds and to identify appropriate methods of extraction to control the oxidative degradation of polyphenols in order to avoid the occurrence of unde- 
sirable reactions such as hydrolysis, oxidation, degradation and rearrangement.

One of the drawbacks for the direct industrial applications of SFE is the high costs. For this reason, this method is associated mainly with high-value products or those required compliance with strict environmental regulations [10].

In this review, a detailed and updated discussion of the developments and applications of supercritical fluid extraction (SFE) in the recovery of phenolic compounds from different matrices is presented.

\section{EVALUATION OF SOME SUPERCRITICAL PA- RAMETERS ON THE RECOVERY OF PHENOLIC COMPOUNDS FROM FOOD SOURCES}

Several researchers studied the extraction process of phenolic phytochemicals in a wide group of representative samples from the food sources. Liquid samples include beverages such as wine, fruit juices, tea, coffee, and beer and some types of vegetable oils. Solid samples comprise fruits, vegetables and cereals as well as plant tissues and byproducts in the manufacture, such as leaves, seeds, peel and skin of fruits and others vegetables.

The use of supercritical fluid extraction (SFE) for the extraction of polyphenols with high antioxidant activities and optimization of the experimental conditions are focused on the evaluation of the effect of the variables that control the whole process. The main targets are to provide maximum yields, preserving highest quality with antioxidant activity, making the final product suitable for use in food, cosmetic or pharmaceutical industries [12]. On the other hand, no references have been found regarding directly to the stability of phenolic compounds during the process and under different supercritical extraction conditions.

Some of the conditions used for the extraction, recovery and characterization of phenolic compounds from food and plants using supercritical extraction were summarized in Table 1.

Table 1. Conditions for the Extraction, Recovery and Characterization of Phenolic Compounds from Food and Plants Using Supercritical Extraction

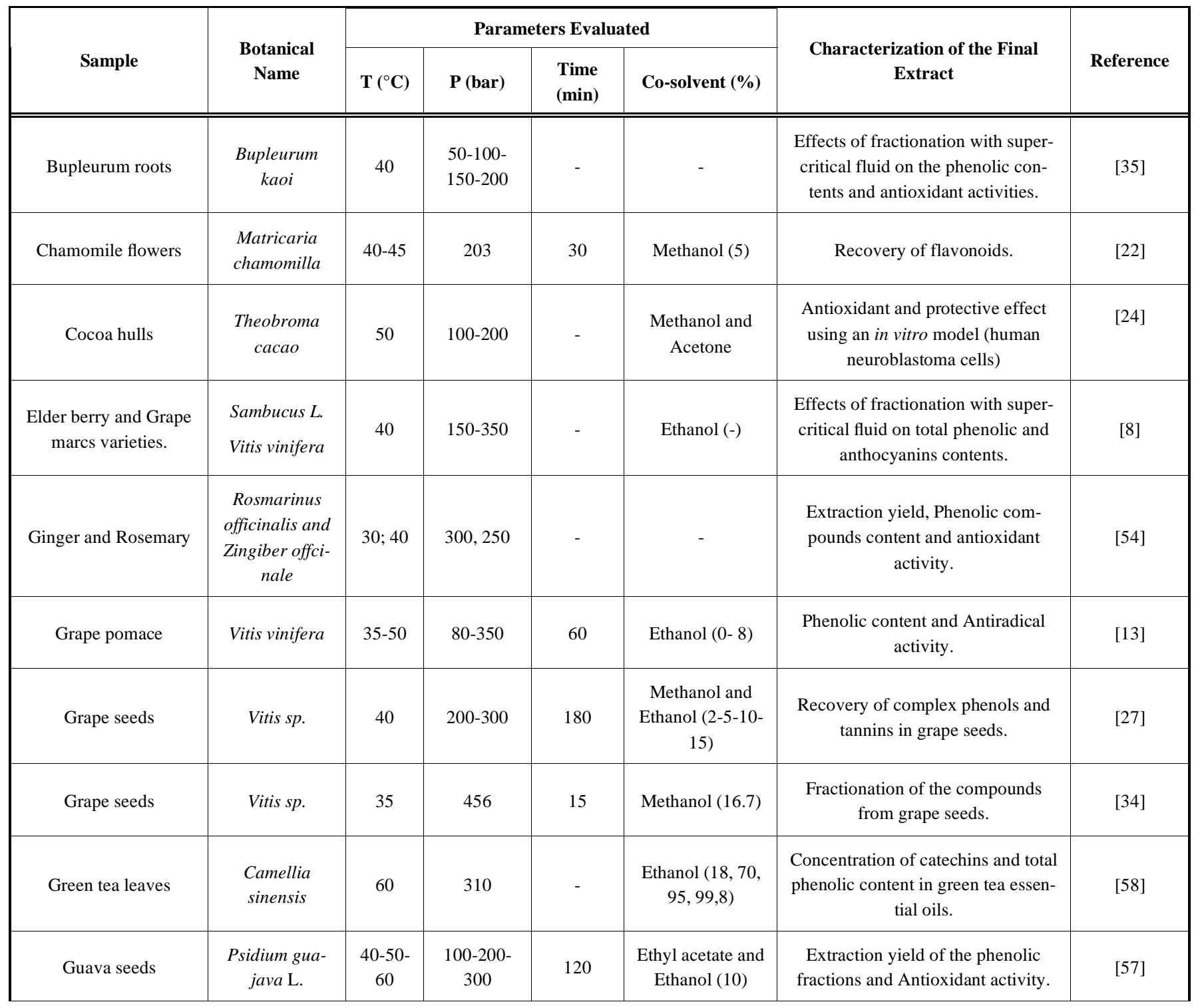


Table 1. contd...

\begin{tabular}{|c|c|c|c|c|c|c|c|}
\hline \multirow[b]{2}{*}{ Sample } & \multirow{2}{*}{$\begin{array}{l}\text { Botanical } \\
\text { Name }\end{array}$} & \multicolumn{4}{|c|}{ Parameters Evaluated } & \multirow{2}{*}{$\begin{array}{c}\text { Characterization of the Final } \\
\text { Extract }\end{array}$} & \multirow[b]{2}{*}{ Reference } \\
\hline & & $\mathbf{T}\left({ }^{\circ} \mathbf{C}\right)$ & $\mathbf{P}($ bar $)$ & $\begin{array}{l}\text { Time } \\
(\min )\end{array}$ & Co-solvent (\%) & & \\
\hline Lamiaceae herbs & $\begin{array}{l}\text { Rosmarinus } \\
\text { officinalis, } \\
\text { Salvia } \\
\text { officinalis, } \\
\text { Thymus vul- } \\
\text { garis and } \\
\text { Hyssop } \\
\text { officinalis }\end{array}$ & 100 & 350 & - & - & $\begin{array}{l}\text { Isolation of antioxidant fractions of } \\
\text { herbs and Antioxidant activity of } \\
\text { the obtained extracts. }\end{array}$ & [59] \\
\hline Mangosteen & $\begin{array}{l}\text { Garcinia man- } \\
\text { gostana }\end{array}$ & 40 & 200 & - & Ethanol (4) & $\begin{array}{c}\text { Characterization of the xathones } \\
\text { and Antioxidant activity of the } \\
\text { obtained extracts. }\end{array}$ & [60] \\
\hline Olive leaves & Olea europaea & $\begin{array}{c}80- \\
100- \\
120\end{array}$ & $155-334$ & $5-140$ & $\begin{array}{l}\text { Methanol and } \\
\text { Ethanol }(0-20)\end{array}$ & Total phenolic content. & {$[20]$} \\
\hline Oregano leaves & $\begin{array}{l}\text { Origanum } \\
\text { vulgare }\end{array}$ & $40-60$ & $\begin{array}{l}150-250- \\
350\end{array}$ & 50 & Ethanol (0- 4- 7) & $\begin{array}{c}\text { Extraction yield and Antioxidant } \\
\text { activity. }\end{array}$ & [26] \\
\hline Pistachio hulls & Pistachia vera & $\begin{array}{c}35- \\
45-55\end{array}$ & $\begin{array}{l}100-200- \\
350\end{array}$ & $15-25-40$ & $\begin{array}{c}\text { Methanol (0 -5- } \\
15)\end{array}$ & $\begin{array}{l}\text { Total phenolic content and Antioxi- } \\
\text { dant activity. }\end{array}$ & [30] \\
\hline Red grape pomace. & Vitis vinifera & 45 & $\begin{array}{l}100-150- \\
250\end{array}$ & - & Methanol (5) & $\begin{array}{l}\text { Effects of pre treatment with super- } \\
\text { critical fluid on the recovery of } \\
\text { phenolic compounds and antioxi- } \\
\text { dant activity. }\end{array}$ & [33] \\
\hline Rosemary leaves & $\begin{array}{c}\text { Baccharis } \\
\text { dracunculifo- } \\
\text { lia }\end{array}$ & $\begin{array}{c}40-50- \\
60\end{array}$ & $\begin{array}{c}200-300- \\
400\end{array}$ & $\begin{array}{l}20 \text { static } \\
\text { period }\end{array}$ & - & $\begin{array}{l}\text { Extraction yield of the 3,5-diprenyl- } \\
\text { 4-hydroxycinnamic acid, 3-prenyl- } \\
\text { 4-hydroxycinnamic acid, p- } \\
\text { coumaric acid and kaempferide. }\end{array}$ & [56] \\
\hline Rosemary leaves & $\begin{array}{l}\text { Rosmarinus } \\
\text { officinalis }\end{array}$ & - & 100 & 60 & - & $\begin{array}{l}\text { Effects of fractionation with super- } \\
\text { critical fluid on the phenolic con- } \\
\text { tents. }\end{array}$ & [3] \\
\hline Rosemary leaves & $\begin{array}{l}\text { Rosmarinus } \\
\text { officinalis }\end{array}$ & 100 & 350 & 40 & Methanol (5) & $\begin{array}{l}\text { Yield of phenolic diterpenes and } \\
\text { Antioxidant activity. }\end{array}$ & [31] \\
\hline Spearmint leaves & $\begin{array}{l}\text { Mentha Spi- } \\
\quad \text { cata }\end{array}$ & $\begin{array}{c}40-50- \\
60\end{array}$ & $\begin{array}{l}100-200- \\
300\end{array}$ & $30-60-90$ & Ethanol ( - ) & Yield of bioactive flavonoids. & [19] \\
\hline Sweet basil & $\begin{array}{c}\text { Ocimum } \\
\text { basilicum }\end{array}$ & $30-50$ & $\begin{array}{l}100-150- \\
200-250- \\
300\end{array}$ & $\begin{array}{c}15-30- \\
45-60\end{array}$ & $\mathrm{H}_{2} \mathrm{O}(1-10-20)$ & $\begin{array}{l}\text { Extraction Yield and Antioxidant } \\
\text { activity. }\end{array}$ & [21] \\
\hline Wheat germ & Triticum spp. & $40-60$ & $148-602$ & $10-60$ & - & $\begin{array}{l}\text { Phenolic and tocopherol contents } \\
\text { and Antiradical activity. }\end{array}$ & [55] \\
\hline
\end{tabular}

The first step in the SFE of phenolic compounds is to optimize the conditions of extraction. Pressure, temperature, dynamic time and the percentage of co-solvent are considered as the most important factors as they play a critical role in the extraction yields, phenolic concentration and antiradical activity of extracts obtained. In general, extracts obtained from SFE show a higher phenolic concentration and antiradical activity than those coming from conventional solidliquid extraction [13].

Experimental data (Table 1) showed that temperatures for SFE of phenolic compounds ranges from 35 to $120^{\circ} \mathrm{C}$, pressures from 50 to 600 bar, time from 5 to 180 minutes and of 
co-solvent from 0 to $20 \%$. For most phenolic compounds, a good recovery rate can be achieved by changing the abovementioned parameters [14].

\section{EFFECT OF TEMPERATURE ON SUPERCRITICAL FIUID EXTRACTION OF PHENOLIC COMPOUNDS}

According to Table 1, it can be found that the temperature used for the extraction of phenolic compounds varies greatly. Values ranging from 35 to $120{ }^{\circ} \mathrm{C}$ can be found. Some phenolic compounds are thermosensitive, and higher extraction temperatures should be carefully used. The density of $\mathrm{CO}_{2}$ at constant pressure is reduced with increasing temperature and leading to reduction of fluid solvent power. The effect of temperature on solute solubility is different at pressures in the critical range. Near the system critical pressure, the fluid density is very sensitive to temperature. A moderate increase in temperature can lead to a large decrease in fluid density, with a consequent reduction in solute solubility [15]. However, the increase in temperature will also accelerate mass transfer and improve the extraction yield [16]. The increase of temperature can increase the vapor pressure of the extractable compounds. Thus, the tendency of the compounds to be extracted is increased as they can pass to the supercritical fluid phase [17]. For a volatile solute, there is competition between its solubility in supercritical carbon dioxide and its volatility [18]. However, it is always difficult to predict the effect of temperature on the extraction yields as phenolic compounds are thermosensitive and high temperatures can decrease solvation power.

In a study conducted by Bimaki [19] for extraction of phenolic compounds of Spearmint leaves (Mentha Spicata L.) the largest average value of yield was obtained at 200 bar and $60{ }^{\circ} \mathrm{C}$; however, temperatures of 40,50 and $60{ }^{\circ} \mathrm{C}$ were evaluated. The compounds from Spearmint leaves were then analyzed by high performance liquid chromatography (HPLC) for quantifying the major bioactive flavonoid compounds. The composition of the extracted yields was greatly impacted by the operating conditions. At the best extraction condition (200 bar, $60{ }^{\circ} \mathrm{C}$ and $60 \mathrm{~min}$ ), luteolin had the highest concentration $(0.657 \mathrm{mg} / \mathrm{g})$ among all the other detected flavonoid compounds.

The effect of the extraction temperature on the amount of phenols extracted from olive leaves was studied by Le Floch [20]. The extraction curves were obtained at three different temperatures $\left(80,100\right.$ and $\left.120^{\circ} \mathrm{C}\right)$, corresponding to $\mathrm{CO}_{2}$ densities of $0.78,0.70$ and $0.63 \mathrm{~g} \mathrm{ml} / 1$, respectively. Although the solvating power of methanol-modified carbon dioxide decreased with decreasing density, raising the temperature increased both the extraction rate and extraction efficiency through increased diffusion and desorption. The amount of phenols extracted at $80^{\circ} \mathrm{C}$ increased with increasing extraction time up to $40 \mathrm{~min}$ beyond which it remained constant. However, greater amounts were extracted at 100 or $120^{\circ} \mathrm{C}$ and no plateau was observed over the period studied (1 h).

In some studies, the temperature does not seem to play a great role on the extraction yields of phenolics. In an investigation done by Leal et al. [21] with Sweet Basil, the temperature did not influence the global extraction of compounds, but the pressure had to be increased when the amount of co-solvent was increased, so that the density of the fluid was increased. The same fact was verified by Scalia et al. [22] in isolation of the active components present in chamomile flowerheads, in which temperatures from 40 to $45^{\circ} \mathrm{C}$ were studied. However, high temperatures were not investigated, since this approach limits the advantages offered by SFE for the isolation of thermally labile flavonoids.

\section{EFFECT OF PRESSURE ON SUPERCRITICAL AIUID EXTRACTION OF PHENOLIC COMPOUNDS}

According to Table 1, the pressure used for the recovery of phenolic compounds seems to vary greatly: from 50 to 602 bar. An increase on pressure can result in an increase in the fluid density, which alters solute solubility. Gomes et al. [23] have indicated that a higher recovery of volatile fractions and a lower recovery of non-volatile fractions are obtained at high pressures. Therefore, it is possible to modify the phenolic composition of supercritical extracts altering extraction pressure.

In a study done by Bimak et al. [19], with extraction of flavonoids spearmint (Mentha spicata L.), the yield increased from $40.69 \mathrm{mg} / \mathrm{g}$ to $51.07 \mathrm{mg} / \mathrm{g}$ with an increase of 100 bar on system pressure (100 to 200 bar). The increase in density of the fluid is the mechanism that explains this process. Above this range of pressure (100-200 bar), a decreasing flavonoid yield with increasing pressure was observed. The volatility and polarity of extracted target compounds might be responsible for the result [16,23]. Le Floch et al. [20], observed the same fact in the extraction of phenolic compounds of olive leaves. The amount extracted increased linearly with increasing pressure. The increase of 155 to 334 bar resulted in an yield increase from $0.59 \mathrm{mg} / \mathrm{g}$ to $3.4 \mathrm{mg} / \mathrm{g}$ at constant temperature of $100^{\circ} \mathrm{C}$, as shown in Fig. (1).

According to Arlório et al. [24], the change in pressure from 150 to 200 bar with constant temperature of $50{ }^{\circ} \mathrm{C} \mathrm{did}$ not cause any change in biological activity of the phenolic compounds extracted from Theobroma cacao hulls. The yields were clearly affected when the samples were redissolved in acetone. A study done by Scalia et al. [22], with extraction of Chamomile flower also showed that the increased pressure of the supercritical $\mathrm{CO}_{2}$ (pressures from 203-405 bar) did not affected the recovery of the two flavonoids investigated (apigenin and apigenin-7-glucoside). In this case, the proportion of co-solvent was the variable that significantly interfered on extraction yields.

\section{EFFECT OF MODIfIERS ON SUPERCRITICAL AIUID EXTRACTION OF PHENOLIC COMPOUNDS}

Among supercritical fluids, carbon dioxide $\left(\mathrm{CO}_{2}\right)$ is the most used solvent because its mild critical conditions (nearly $31.1^{\circ} \mathrm{C}$ and 74.0 bar), readily separation from solutes, nontoxic properties and GRAS status [8,10,25]. Characteristics of a supercritical fluid resemble both a gas and a liquid, the gas-like characteristics help the fluids diffusion to the matrix and access to the phytochemicals and the liquid-like characteristics provides good solvation power [14].

Supercritical $\mathrm{CO}_{2}$ has good solvent properties for extraction of non-polar compounds and some moderately polar compounds such as phenolic acids and their esters [25]. Supercritical carbon dioxide is often used to recover non-polar compounds [26]. Phenolic compounds are more hydrophilic, and neat $\mathrm{CO}_{2}$ is not widely used for their extraction. Never- 


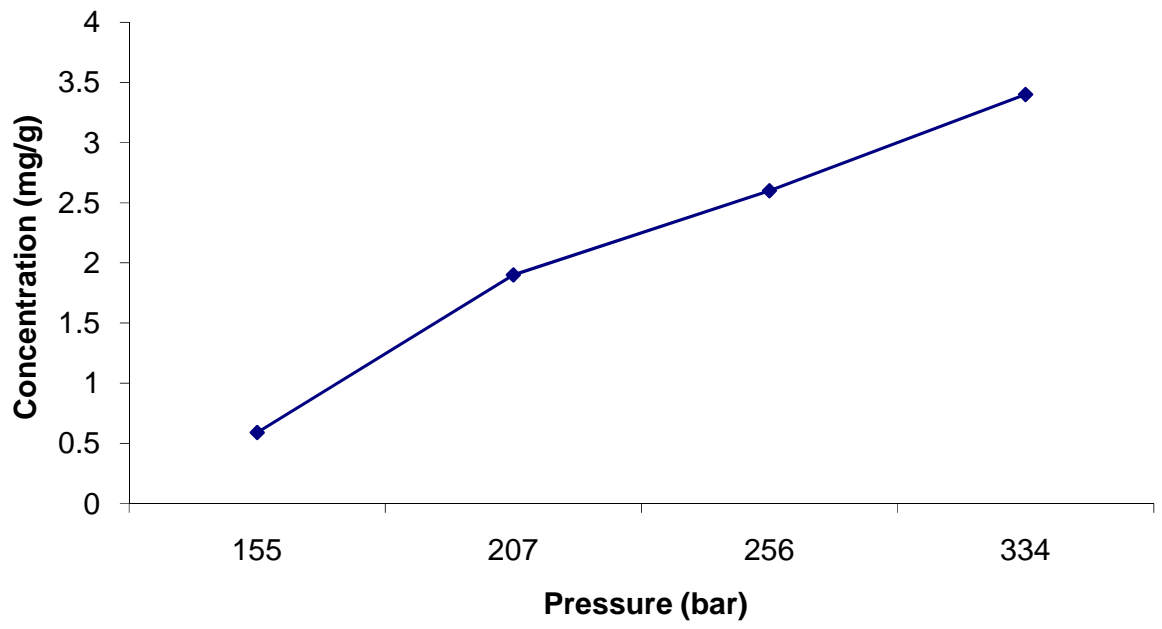

Fig. (1). Influence of the extraction pressure on the SFE efficiency of phenols from olive leaves, adapted from [20].

theless, a common practice in SFE is to change the polarity of the supercritical fluid and increase on the solvating power towards the target compounds by addition of small amounts of organic co-solvents like ethanol and methanol. The cosolvents interact strongly with analytes improving significantly the extraction yields. Ethanol and methanol are capable of hydrogen-bonding, dipole-dipole and others polarity interactions with phenols, which make them interesting for the recovery these compounds $[25,27,28]$.

Moreover, the different antioxidant activities of phenolic extracts can be attributed to different extracting solvent, since the antioxidant activity depends on the type and polarity of the extracting solvent, besides the isolation procedures and the purity of active compounds [29].

Supercritical $\mathrm{CO}_{2}$ extraction with ethanol and/or methanol has been applied to extract polyphenolics from different vegetable raw materials. Cavero et al. [26] studied supercritical fluid extraction of oregano leaves to obtain antioxidants using different amount of ethanol as co-solvent (4 and $7 \%$ ). Comparing the co-solvent extraction yields with SFE using neat $\mathrm{CO}_{2}$, it was found that the use of a co-solvent increases the extraction yields and the highest antioxidant activity was found in those extracts obtained using ethanol as modifier.

Goli et al. [30] evaluated the effect of different percentages of methanol $(0,5$ and $15 \%)$ on total phenolic in pistachio hulls and compared to solvent extraction and solvent extraction by sonication employing water, methanol and ethyl acetate. The authors concluded that the maximum phenolic content ( $7.8 \mathrm{mg} \mathrm{TAE} / \mathrm{gdw}$ ) was obtained at $356 \mathrm{bar}$, $45^{\circ} \mathrm{C}$ and $15 \%$ of co-solvent. However, this result, in comparison with solvent extraction (with or without sonication) was low. Higher extraction yields of phenolic compounds were obtained with an increase in polarity of the solvent.

Murga et al. [27] studied the feasibility of application of supercritical fluids for selective extraction of complex phenol and tannins from grape seeds. Two variables were used to improve selectivity: pressure (200 and 300 bar), type and amount of co-solvent $(2,5,10$, and $15 \%$ ethanol or methanol). The results showed that varying the amount of cosolvent and pressure the compounds of interest are selectively recovered. Mixtures with low percentage of co-solvent extracted some of the low molecular weight phenols, such as gallic acid, protocatechuic acid, and protocatechuic aldehyde. A progressive increase in pressure and percentage of co-solvent allowed extraction of increasing molecular weight phenols. Methanol and ethanol showed results qualitatively similar.

In order to investigate antioxidant activities of supercritical $\mathrm{CO}_{2}$ extracts of rosemary leaves, Celiktas and coworkers [31] employed various co-solvents and at different percentages: $2 \%$ and $5 \%$ of methanol, ethanol and propanol. At 350 bar, $100^{\circ} \mathrm{C}, 40 \mathrm{~min}$ and $5 \%$ methanol, the amounts of carnosol and carnosic acid in the extracts were $15.8 \%$ and $143 \%$ higher, respectively, than the amounts obtained under the same conditions without use of co-solvent.

Supercritical fluid extraction method for the isolation of phenols from olive leaves was examined by Le Floch and partners [20]. The amount of total phenols extracted from samples with pure $\mathrm{CO}_{2}$ and various methanol and ethanol$\mathrm{CO}_{2}$ mixtures was examined at $100^{\circ} \mathrm{C}$ and 344 bar. The addition of $10 \%$ methanol provided the highest recovery of phenols. Ethanol was found to be useful as a co-solvent, but less effective than methanol under the same conditions $(2 \mathrm{mg} / \mathrm{g}$ and $3.6 \mathrm{mg} / \mathrm{g}$ of caffeic acid, respectively).

Although methanol is the best solvent for improving phenolic molecules extraction, ethanol may be a better choice in SFE because of its lower toxicity (solvent recognized as safe - GRAS) and possible future application of the extracted polyphenols in food, cosmetic and pharmaceutical products [32].

On another way, SFE using neat carbon dioxide has been employed in the pre-treatment of natural materials, mainly for the purification of the primary extract in order to remove the non-polar compounds. After this treatment the polar polyphenols became more accessible for further extraction process. Furthermore, extractions with supercritical $\mathrm{CO}_{2}$ $\left(\mathrm{scCO}_{2}\right)$ result in solvent-free products and avoid deteriorating reactions, due to low process temperatures $[8,33]$.

This approach has been used to extract some phenolics fractions from cocoa hulls [24], grape seeds [34], Bupleurum kaoi [35], elder berry, and wine by-product [8,33]. In general, the investigations showed that samples $\mathrm{scCO}_{2}$ pretreatment resulted on significant enrichment on phenolic 


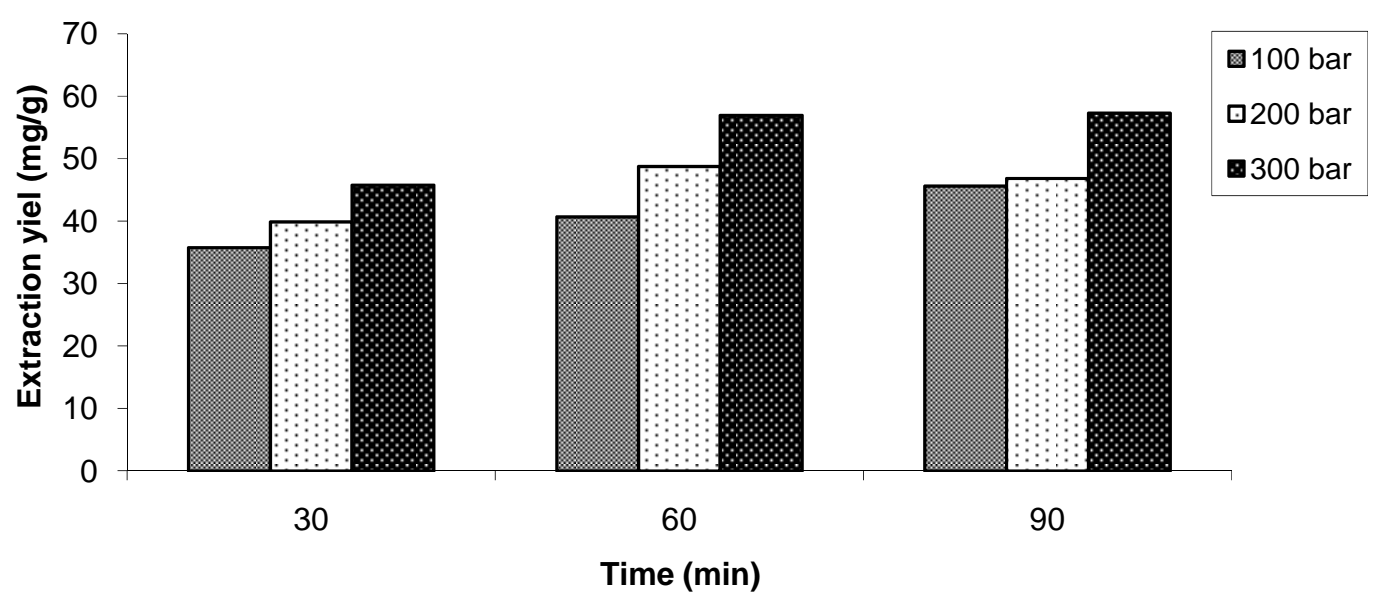

Fig. (2). Effect of Dynamic Extraction Time on the Extraction Yield of Crude Extract, adapted from [19].

compounds due to the remove of non-polar fraction. As a result, the antioxidant properties are also improved, since the contents of total phenol compounds and antioxidant capacity are related to each other $[13,36]$.

\section{EFFECT OF EXTRACTION TIME ON SUPERCRITI- CAL FIUID EXTRACTION OF PHENOLIC COM- POUNDS}

It is important to maximize the contact of the supercritical solvent with the sample material in order to enhance the efficiency of recovery yield. Several variables can influence the solvent contact with sample material which includes flow rate, SFE time, and SFE mode (static or dynamic) [18]. The analysis of process can be performed considering the overall extraction curves (OEC). OEC is obtained by taking into consideration the amount extracted (mass of extract or yield) in relation to time. This curve generally presents three stages: a constant extraction rate period (CER), where the solute is easily transferred from solid to fluid phase; followed by a falling extraction rate period (FER), and finally, the diffusion controlled rate period (DC) [21].

The main information contained in OEC is the time required for extraction process to obtain an economical advantageous process regarding time and extraction yields.

Granted that supercritical fluid extraction process involves high investment costs and total cost increases with increase in extraction time, it is very important to optimize processes parameters. Commonly, the minimum cost of manufacturing is obtained in extraction times close to the end of the constant extraction rate region (CER), in which the lowest time and highest rates of recovery of target compounds are observed [37].

Bimark et al. [19] showed the influence of dynamic extraction time on the extraction yields of spearmint leaves. They first evaluated static extraction with supercritical carbon dioxide using $30 \mathrm{~min}$, followed dynamic extraction using 30, 60 and $90 \mathrm{~min}$. The results showed that, at 100 bar, the extraction yield was increased with dynamic time until $90 \mathrm{~min}$. However, at higher pressures (200 and 300 bar) the extraction yield increased with dynamic extraction time until 60 min, as shown in the Fig. (2).

The influence of the dynamic time on extraction of phenols in olive leaves was studied by Le Floch and coworkers
[20]. Samples were subjected to static supercritical fluid extraction (SFE) for $1 \mathrm{~min}$, followed by dynamic extraction 5140 min (depending on the particular experiment). The extraction curve obtained under the optimal SFE conditions showed the accumulative amount of phenols extracted at 20$\min (6.7 \mathrm{mg} / \mathrm{g})$ to $140-\mathrm{min}$ extraction $(8.0 \mathrm{mg} / \mathrm{g})$. The highest yield was achieved after $140 \mathrm{~min}$. It was found that increased dynamic extraction time enhances the extraction of most of the phenolic compounds; however, the authors stated that according to economic aspects, the time should be minimized.

\section{STABILITY OF EXTRACTS RICH IN PHENOLIC COMPOUNDS}

Phenolic compounds are highly unstable and very susceptible to degradation. Their stability is affected by several factors such as light, oxygen, temperature, solvents and presence of enzymes. Moreover, their stability depends on the specific molecular structure and the composition of the matrix in which they exist [34]. All factors mentioned above, related to the instability of these compounds, must be considered from samples handling procedures, to the storage conditions of extracts. The extractions conditions can vary a great deal depending on the nature of the analyte (total phenolics, specific phenolic classes or individual compounds) and type of matrices [38].

The traditional extraction methods such as liquid-liquid, solid-liquid and Soxhet extractions are the most commonly used procedures prior to analysis of polyphenolics and simple phenolics in plant materials [6]. However, these methods can involve lengthy extraction times, moderately high temperatures, presence of the light and oxygen, handling of large volumes of hazardous solvents and extended concentration steps which give rise to possible degradations or loss of phenolic compounds [22]. Deteriorative processes can be originated by both external and internal factors. Light, together with air and temperature, are the most specific accelerating agents [29,39].

In general, high temperatures result in higher extraction rates and minimize the duration of the process, but too high temperatures result in lower phenolic compounds yield, due to structural degradation into biologically inactive forms and interactions with some other cellular components [40, 41]. Degradation kinetics during heating depends mainly on both 
<smiles>CCOc1cc(-c2[o+]c3cc(O)cc(O)c3cc2O)cc(O)c1O</smiles><smiles>CCOc1cc(C(=O)/C(=C\c2c(O)cc(O)cc2O)Oc2ccccc2)cc(O)c1O</smiles>

red flavylium cation

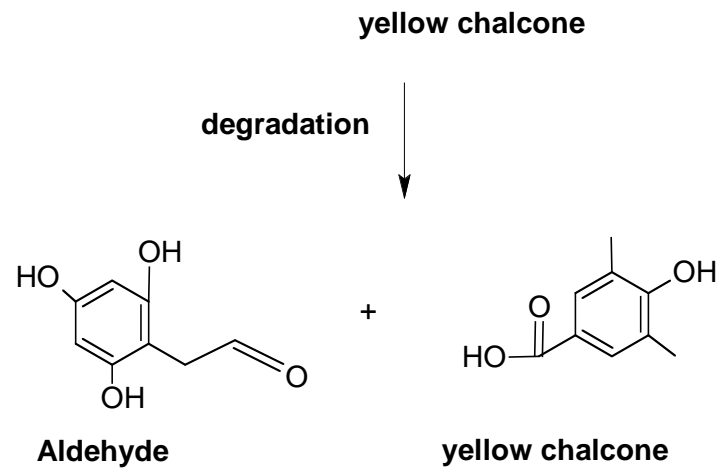

Fig. (3). Anthocyanins chemical forms at different $\mathrm{pH}$ levels and degradation reaction of anthocyanins. $\mathrm{R}_{1}=\mathrm{H}$ or glycosidic substituent, $\mathrm{R}_{2}$ and $\mathrm{R}_{3}=\mathrm{H}$ or $\mathrm{CH}_{3}$.

the specific phenolic composition and characteristics of matrix (eg. concentrations of some non-phenolic compounds and the presence of oxidation catalysts) [42].

Oxygen also plays a vital role in the phenolic compounds degradation processes [43]. The presence of oxygen can accelerate the degradation of these compounds either through a direct reaction of molecular oxygen with the phenols and/or catalyzed by enzymes in presence of oxygen. Many plant tissues have a high enzyme activity. Enzymes present in the sample, principally oxidative enzymes, such as polyphenoloxidases, peroxidases, glycosidases and esterases, are liberated during the extraction and promote transformations and degradations of polyphenolic compounds, though the structures of resulting products are still poorly understood [44]. According to Devllin and Harris (1984) [45], at elevated temperatures and aqueous medium, oxygen can react with of phenols in different ways: it can substitute an oxygen atom into an aromatic ring to form a dihydric phenol or quinone and attacking carbon to carbon double bonds to form carbonyl compounds, and in oxidizing alcohols and carbonyl groups to form carboxylic acids.

In anthocyanins, degradation is primarily caused by oxidation, cleavage of covalent bonds or enhanced oxidation reactions due to thermal treatment. Thermal degradation of anthocyanins can result in a variety of species depending upon the severity and nature of heating. According to some authors, one possible thermal degradation mechanisms of anthocyanins is hydrolysis of sugar moiety, as initial degradation step, and cleavage of aglycone resulting in different benzoic acids or aldehyde derivatives [43].

Moreover, polyphenols are generally light sensitive and hence extreme care must be taken to ensure proper extraction and minimize light induced degradation, devoid of chemical modification and protect it from oxidation [40].
The stability of the phenolic compounds strongly is depended on the $\mathrm{pH}$ of the solvent system. Several studies have been indicated that the extraction $\mathrm{pH}$ value significantly affects the extraction yield and antioxidant activities compared with other factors [46].

The stability of an acylated derivatives from apigenin-7glucoside present in chamomile (Chamomilla recutita [L.]), were studied using different temperatures, $\mathrm{pH}$ and solvents. Light was found to have no significant effect on the degradation of the flavonoids, but higher temperatures increased the rate of flavonoid degradation. The compounds showed different stabilities depending on the $\mathrm{pH}$ [47].

Another investigation shows the influence of temperature (between $50{ }^{\circ} \mathrm{C}$ and $150{ }^{\circ} \mathrm{C}$ ), atmospheric oxygen and light on the degradation of $\alpha$-tocopherol. The temperature showed to be the major factor responsible for $\alpha$-tocopherol degradation, especially above $100{ }^{\circ} \mathrm{C}$. The action of the light was negligible, implying that the degradation occurred due to autoxidation rather than photoxidation. Moreover, the interaction between atmospheric oxygen and temperature increased the degradation. But the interaction showed to be insignificant at temperatures over $100{ }^{\circ} \mathrm{C}$. The degradation rate in the experimental conditions ranged from 0.6 to 36 $\mathrm{ppm} \mathrm{h}^{-1}$ at $50{ }^{\circ} \mathrm{C}$ in the absence of light and atmospheric oxygen, and at $150{ }^{\circ} \mathrm{C}$ with light and atmospheric oxygen, respectively [48].

The color, intensity and stability of anthocyanins in aqueous media also change significantly in the $\mathrm{pH}$ range [49]. The well known red color of anthocyanins is present only at low pH in aqueous solution. Fig. (3) shows a general scheme of the stability of anthocyanins according to $\mathrm{pH}$. By raising the $\mathrm{pH}$ above 4 , yellow, colorless, and blue compounds can be produced. Anthocyanins exhibit the highest stability as the red flavylium cation around $\mathrm{pH} 1-2$, whereas 
the other forms, especially the pale yellow chalcone, are unstable and eventually lead to the degradation of the anthocyanins. At $\mathrm{pH}$ values higher than 7 , the anthocyanins are generally degraded depending on their substituent groups [9]. In blueberry juices, the content of monomeric anthocyanins, total phenolic content and antioxidant capacity was greater in samples at $\mathrm{pH}=1$ than in $\mathrm{pH}=4$ and 7 [50]. In cereals, most efficient antioxidant extraction was achieved by using acidic solvent at $\mathrm{pH}=2$ [51]. The inhibition of phenolics enzymatic oxidation and/or the maintenance of the extracted anthocyanin stability were improved at low $\mathrm{pH}$ conditions [46]. In this way, SFE conditions can be really advantageous for stability of phenolic compounds since the presence of water in matrix in contact with carbon dioxide results in the formation and dissociation of carbonic acid which lowers the $\mathrm{pH}$ of the aqueous phase to approximately 3 [52].

In these instances, supercritical fluid extraction due to the operational conditions of extraction offers great advantages for the recovery of highly reactive phenolic molecules. SFE is usually performed in inert atmospheres, absence of light, at low temperatures and less time. Hence, all this factors contribute to avoid oxidation, thermal degradation and other chemical and biochemical changes common in phenolic compounds [29].

Pinelo and coworkers [13] compared phenolic content and the antiradical activity of extracts obtained from grape pomace by using solid-liquid and supercritical fluid extraction. In general, extracts obtained from supercritical extraction, showed a higher phenolic concentration and antiradical activity than those coming from solid-liquid extraction, corroborating the efficiency of SFE for the recovery of phenolic compounds.

In general terms, the composition of the extract depends highly on the solvent used, extraction technique, origin of the plant material, different types of tissues (leaves, stems, seeds, etc.) and other variables, like pretreatment and storage conditions [33]. According to Robards [53], there are not well established procedures for the storage of extracts containing high concentrations of phenolic compounds. But, the storage of extracts rich in phenolic compounds in a dark, under vacuum, at low temperatures, is a good option considering the factors that lead to the degradation of these compounds.

All these conditions should be taken into account in order to produce a high quality extract with antioxidant activity suitable for use in food, cosmetic or pharmaceutical industry [33].

Supercritical technology can also be used to produce nanoparticles; however, these particulation processes are under development stage. Little information is available considering the production of nanoparticles using supercritical fluids, especially for phenolic compounds.

Nowadays, food market receives many products with different claims about possible contributions to health. Probably new food products will tend to emerge following this tendency. Certainly, the bioavailability will be a topic of interest. As phenolic compounds are well known by their health potential, a topic of future interest in research will be certainly the maximization of bioavailability of phenolic com- pounds. One could say that phenols are quite soluble in gastrointestinal transit, however, there is not a consensus about their absorption and metabolism.

In this way, techniques for phenolic compounds particle formation will be a topic of interest. Considering the great potential of supercritical technology for phenols extraction and stabilization, this technology could be applicable for phenols particle formation in a near future.

\section{CONCLUSION}

In this paper, an evaluation of the extraction parameters for supercritical extraction of phenolic compounds is presented. The definition of the correct parameters to the extraction of phenolic compounds is a special target for SFE. Phenolic compounds are commonly interesting to food, cosmetic and pharmaceutical industries. The stabilization of such supercritical extracts rich in phenolics is also a topic of interest as these compounds are generally unstable if mild storage conditions are not used. In this way, more investigations related to optimization of extraction and stabilization conditions tend to emerge.

\section{ACKNOWLEDGEMENTS}

AVL and NRVD are grateful for financial support from the $\mathrm{CNPq}$ - Process numbers 133001/2008-3 and 131611/2009-7, respectively.

\section{REFERENCES}

[1] I. Konczak, and W. Zhang, "Anthocyanins-more than nature's colours", J. Biomed. Biotechnol., vol. 5, pp. 239-240, 2004.

[2] N. C. Cook, and S. Samman, "Flavonoids - Chemistry, metabolism, cardioprotective effects, and dietary sources", J. Nutr. Biochem., vol. 7, pp. 66-74, 1996.

[3] P. Ramírez, T. Fornari, F. J. Señoráns, E. Ibãnez, and G. Reglero, "Isolation of phenolic antioxidant compounds by SFC", J. Supercrit. Fluids, vol. 35, pp.128-132, 2005.

[4] L. Gao, and G. Mazza, "Extraction of anthocyanin pigments from purple sunflower hulls", J. Food Sci., vol. 61, pp. 600-603, 1996.

[5] K. Pyrzynska, and M. Biesaga, "Analysis of phenolic acids and flavonoids in honey", Trends Anal. Chem., vol. 28, pp. 893-902, 2009.

[6] C. D. Stalikas, "Extraction, separation, and detection methods for phenolic acids and flavonoids", J. Sep. Sci., vol.30, pp. 3268 3295, 2007.

[7] M. P. Kähkönen, A.I. Hopia, and M. Heinonen, "Berry phenolics and their antioxidant activity", J. Agric. Food Chem., vol. 49, pp. 4076-4082, 2001.

[8] T. Vatai, M. Škerget, and Ž. Knez, "Extraction of phenolic compounds from elder berry and different grape marc varieties using organic solvents and/or supercritical carbon dioxide", J. Food Eng., vol. 90 , pp. 246-254, 2009.

[9] A. Castañeda-Ovando, M.L. Pacheco-Hernández, M.A. PáezHernández, J.A. Rodríguez, and C.A. Galán-Vidal, "Chemical studies of anthocyanins: a review", Food Chem., vol.113, pp. 859-871, 2009.

[10] J. Sunarso, and S. Ismadji, "Decontamination of hazardous substances from solid matrices and liquids using supercritical fluids extraction: a review", J. Hazard. Mater., vol. 161, pp. 1-20, 2009.

[11] M. Bleve, L. Ciurliaa, E. Erroi, G. Lionetto, L. Longo, L. Rescio, T. Schettino, and G. Vasapollo, "An innovative method for the purification of anthocyanins from grape skin extracts by using liquid and sub-critical carbon dioxide" Sep. Purif. Technol., vol. 64, pp.192-197, 2008.

[12] G. Spigno, L. Tramelli and D. M. Faveri, "Effects of extraction time, temperature and solvent on concentration and antioxidant activity of grape marc phenolics", J. Food Eng., vol. 81, pp. 200-208, 2007.

[13] M. Pinelo, A. Ruiz-Rodríguez, J. Sineiro, F. J. Señoráns, G. Reglero and M. J. Núñez, "Supercritical fluid and solid-liquid extrac- 
tion of phenolic antioxidants from grape pomace: a comparative study”, Eur. Food Res. Technol., vol. 226, pp. 199-205, 2007.

[14] R. Tsao and Z. Deng, "Separation procedures for naturally occurring antioxidant phytochemicals", J. Chromatogr. B, vol. 812, pp. 85-99, 2004.

[15] R. K. Roop, A. Akgerman, B.J. Dexter, and T. R. Irvin, "Extraction of Phenol from water with supercritical carbon dioxide", J. Supercrit. Fluids, vol. 2, pp. 51-56, 1989.

[16] L. B. Wang, X. Yang, Du, and C., Yi,, "Optimisation of supercritical extraction of flavonoids from Pueraria lobata", Food Chem., vol. 108, pp. 737- 741, 2008.

[17] E. Reverchon, and I. De-Marco, "Supercritical Fluid Extraction and Fractionation of Natural Matter", J. Supercrit. Fluids, vol. 38, pp. 146-166, 2006.

[18] S. M. Pourmortazavi, and S. S. Hajimirsadeghi, "Supercritical fluid extraction in plant essential and volatile oil analysis", J. Chromatogr. A, vol. 1163, pp. 2-24, 2007.

[19] M. Bimakr, R. A. Rahman, F. S. Taip, L. T. Chuan, A. Ganjloo, J. Selamat, and A. Hamid, "Supercritical carbon dioxide (SC-CO2) extraction of bioactive flavonoid compounds from spearmint (Mentha Spicata L.) leaves", Eur. J. Sci. Res., vol.33, no. 4, pp.679-690, 2009.

[20] F. Le Floch, M.T. Tena, A. Ríos, and M. Valcárcel, "Supercritical fluid extraction of phenol compounds from olive leaves", Talanta, vol. 46, pp.1123-1130, 1998.

[21] P. F. Leal, N. B. Maia, Q. A. C. Carmello, R. R. Catharino, M. N. Eberlin, and M. Angela A. Meireles, "Sweet basil (Ocimum basilicum) extracts obtained by supercritical fluid extraction (SFE): Global Yields, Chemical Composition, Antioxidant Activity, and Estimation of the Cost of Manufacturing", Food Bioprocess Technol., vol.1, pp. 326-338, 2008.

[22] S. Scalia, L. Giuffreda, and P. Pallado, "Analytical and preparative supercritical fluid extraction of Chamomile flowers and its comparison with conventional methods", J. Pharm. Biomed., vol. 21, pp. 549-558, 1999.

[23] P. B. Gomes, V. G. Mata, and A.E. Rodrigues, "Production of rose geranium oil using supercritical fluid extraction", J. Supercrit. Fluids, vol. 41, pp. 50-60, 2007.

[24] M. Arlorio, J.D. Coïsson, F. Travaglia, F. Varsaldi, G. Miglio, G. Lombardi, and A. Martelli, "Antioxidant and biological activity of phenolic pigments from Theobroma cacao hulls extracted with supercritical $\mathrm{CO}_{2}$ ", Food Res. Int., vol. 38, pp.1009-1014, 2005.

[25] Q. Lang, and C. M. Wai, "Supercritical fluid extraction in herbal and natural product studies - a practical review", Talanta, vol. 53, pp. 771-782, 2001.

[26] S. Cavero, M. R. García-Risco, F. R. Marín , L. Jaime , S. Santoyo, F. J. Señoráns, G. Reglero, and E. Ibañez, "Supercritical fluid extraction of antioxidant compounds from oregano Chemical and functional characterization via LC-MS and in vitro assays", J. Supercrit. Fluids, vol. 38, pp. 62-69, 2006.

[27] R. Murga, R. Ruiz, S. Beltrán, and J. L. Cabezas, "Extraction of natural complex phenols and tannins from grape seeds by using supercritical mixtures of carbon dioxide and alcohol", J. Agric. Food Chem., vol. 48, pp. 3408-3412, 2000.

[28] J. A. Mendiola, and M. Herrero, A. Cifuentes and E. Ibãnez, "Use of compressed fluids for sample preparation: food applications", $J$. Chromatogr. A, vol. 1152, pp. 234-246, 2007.

[29] D. Tura and K. Robards, "Sample handling strategies for the determination of biophenols in food and plants", J. Chromatogr. A, vol. 975, pp. 71-93, 2002.

[30] A. H. Goli, M. Barzegar, and M. A. Sahari, "Antioxidant activity and total phenolic compounds of pistachio (Pistachia vera) hull extracts", Food Chem., vol. 92, pp. 521-525, 2005.

[31] O. Y. Celiktas, E. Bedir, and F. V. Sukan, "In vitro antioxidant activities of Rosmarinus officinalis extracts treated with supercritical carbon dioxide", Food Chem., vol. 10, pp. 1457-1464, 2007.

[32] I. H. Adil, H. I. Çetin, M.E. Yener, and A. Bayındırl, "Subcritical (carbon dioxide + ethanol) extraction of polyphenols from apple and peach pomaces, and determination of the antioxidant activities of the extracts", J. Supercrit. Fluids, vol. 43, pp. 55-63, 2007.

[33] V. Louli, N. Ragoussis and K. Magoulas, "Recovery of phenolic antioxidants from wine industry by-products", Bioresour. Technol., vol. 92, pp. 201-208, 2004.

[34] M. Palma, Z. Piñeiro, and C.G. Barroso, "Stability of phenolic compounds during extraction with superheated solvents", J. Chromatogr. A, vol. 921, pp. 169-174, 2001.
[35] B.J. Wang, C.T. Liu, C.Y. and Tseng, Z.R. Yu.”Antioxidant activity of Bupleurum kaoi Liu (Chao et Chuang) Fractions fractionated by supercritical $\mathrm{CO}_{2}$ ", $L W T$, vol. 38, pp. 281-287, 2005.

[36] L. Wang, and C. L. Weller, "Recent advances in extraction of nutraceuticals from plants", Trends Food Sci. Technol., vol. 17, pp. 300-312, 2006.

[37] P.T.V. Rosa, and M.A.A. Meireles. Rapid estimation of manufacturing cost of extracts obtained by supercritical fluid extraction. $J$. Food Eng., vol. 67, pp. 235-240, 2005a.

[38] M. Antolovich, P. Prenzler, K. Robards, and D. Ryan, "Sample preparation in the determination of phenolic compounds in fruits", Analyst, vol.125, pp. 989-100, 2000.

[39] J. Wang, X. Xiao, and G. Li, "Study of vacuum microwave-assisted extraction of polyphenolics compounds and pigment from Chinese herbs", J. Chromatogr. A, vol. 1198-1199, pp. 45-53, 2008.

[40] J. Shi, H. Nawaz, J. Pohorly, G. Mittal, Y. Kakuda, and Y. Jiang, "Extraction of polyphenolics from plant material for functional foods - engineering and technology", Food Rev. Int., vol. 21, pp. 139-166, 2005.

[41] A. Liazid, M. Palma, J. Brigui, and C.G. Barroso, "Investigation on phenolic compounds stability during microwave-assisted extraction", J. Chromatogr. A, vol. 1140, pp. 29-34, 2007.

[42] M. Cisse, F. Vaillant, O. Acosta, C. Dhuique-Mayer, and M. Dornier, "Thermal degradation Kinetics of anthocyanins from blood orange, blackberry, and roselle using the Arrhenius, eyring, and ball Models", J. Agric. Food Chem., vol. 57, pp. 6285-6291, 2009.

[43] A. Patras, N.P. Brunton, C. O’Donnell, and B.K. Tiwari, "Effect of thermal processing on anthocyanin stability in foods; mechanisms and kinetics of degradation", Trends Food Sci. Technol., doi:10.1016/j.tifs.2009.07.004, 2009.

[44] V. Cheynier, "Polyphenols in foods are more complex than often thought", Am. J. Clin. Nutr., vol. 81, pp. 223S-229S, 2005.

[45] H. R. Devlln, and I.J. Harris "Mechanism of the oxidation of aqueous phenol with dissolved oxygen." Ind. Eng. Chem. Fundam., vol. 23, pp. 387-392, 1984.

[46] N. Ruenroengklin, J. Zhong, X. Duan, B. Yang, J. Li, and Y. Jiang, "Effects of various temperatures and $\mathrm{pH}$ values on the extraction yield of phenolics from litchi fruit pericarp tissue and the antioxidant activity of the extracted anthocyanins", Int. J. Mol. Sci., vol. 9, pp. 1333-1341, 2008.

[47] V.S. Svehlíková, R.N. Bennett, F.A. Mellon and P.W. Needs, "Isolation, identification and stability of acylated derivatives of apigenin 7-O-glucoside from chamomile (Chamomilla recutita [L.]Rauschert)", Phytochemistry, vol. 65, pp. 2323-2332, 2004.

[48] S. Bostyn, F. Duval-Onen, C. Porte, J. Corc, and H. Fauduet, "Kinetic modelling of the degradation of the a-tocopherol in biodieselrape methyl ester", Bioresour. Technol., vol. 99, pp. 6439-6445, 2008.

[49] L. Cabrita, T. Fossen, and Ø. M. Andersen, "Colour and stability of the six common anthocyanidin 3-glucosides in aqueous solutions", Food Chem., vol. 68, no. 1, pp. 101-107, 2000.

[50] W. Kalt, W. McDonald and H. Donner, "Anthocyanins, phenolics, and antioxidant capacity of processed lowbush blueberry products", J. Food Sci., vol. 65, pp. 390-393, 2000.

[51] J. Perez-Jimenez, and F. Saura-Calixto, "Literature data may underestimate the actual antioxidant capacity of cereals", J. Agric. Food Chem., vol. 53, pp. 5036-5040, 2005.

[52] K. L Toews, R.M. Shroll, and C.M. Wai, " $\mathrm{pH}-$ Defining equilibrium between water and supercritical $\mathrm{CO}_{2}$. influence on SFE of organics and metal chelates", Anal. Chem., vol. 67, pp. 4040-4043, 1995.

[53] K. Robards, "Strategies for the determination of bioactive phenols in plants, fruit and vegetables", J. Chromatogr. A, vol. 1000, pp. 657-691, 2003.

[54] O.R. Justo, A.M. Moraes, G.P.M. Barreto, A.Z. Mercadante, and P.T.V. Rosa, "Avaliação do potencial antioxidante de extratos ativos de plantas obtidos por extração com fluido supercrítico”, Quim. Nova, vol. 31, pp. 1699-1705, 2008.

[55] N. Gelmez, N.S. Kincal, and M.E.Yener, "Optimization of supercritical carbon dioxide extraction of antioxidants from roasted wheat germ based on yield, total phenolic and tocopherol contents, and antioxidant activities of the extracts. J. Supercrit. Fluids, vol. 48, pp. 217-224, 2009.

[56] C. R. Piantino, F.W.B. Aquino, L. A. Follegatti-Romero and F. A. Cabral, "Supercritical $\mathrm{CO}_{2}$ extraction of phenolic compounds from Baccharis dracunculifolia", J. Supercrit. Fluids, vol. 47, pp. 209214, 2008. 
[57] H.I. Castro V., L.I. Rodríguez V., S.R.S. Ferreira and F. Parada A, "Extraction of phenolic fraction from guava seeds (Psidium guajava L.) using supercritical carbon dioxide and co-solvents" J. Supercrit. Fluids, doi:10.1016/j.supflu.2009.10.012, 2009.

[58] C. J. Chang, K. Chiu, Y. Chen, and C.Y. Chang, "Separation of catechins from green tea using carbon dioxide extraction", Food Chem., vol. 68, pp. 109-113, 2000.

[59] N. Babovic, S. Djilas, M. Jadranin, V. Vajs, J. Ivanovic, S. Petrovic, and I. Zizovic, "Supercritical carbon dioxide extraction of antioxidant fractions from selected Lamiaceae herbs and their antioxidant capacity", Innov. Food Sci. Emerg., doi:10.1016/j.ifset. 2009.08.013, 2009.

[60] A.S. Zarena, and K.U. Sankar, "Supercritical carbon dioxide extraction of xanthones with antioxidant activity from Garcinia mangostana: Characterization by HPLC/LC-ESI-MS”, J. Supercrit. Fluids, vol. 49, pp. 330-337, 2009

Received: August 28, 2009

(C) Junior et al.; Licensee Bentham Open.

This is an open access article licensed under the terms of the Creative Commons Attribution Non-Commercial License (http://creativecommons.org/licenses/by-nc/3.0/) which permits unrestricted, non-commercial use, distribution and reproduction in any medium, provided the work is properly cited. 